\title{
A diffuse intrinsic pontine glioma in a neonate diagnosed by MRI
}

\author{
Brandon C Gabel, ${ }^{1}$ Janet Yoon, ${ }^{2}$ Michael L Levy, ${ }^{1}$ John Ross Crawford ${ }^{3}$
}

${ }^{1}$ Department of Neurosurgery, University of California San Diego, San Diego, California, USA

${ }^{2}$ Department of Pediatrics, University of California San Diego, San Diego, California, USA ${ }^{3}$ Department of Neurosciences and Pediatrics, University of California San Diego, San Diego, California, USA

Correspondence to Dr John Ross Crawford, jrcrawford@ucsd.edu

\section{DESCRIPTION}

A 4-day-old full-term girl with a maternal history of polyhydramnios during the third trimester was transferred from an outside nursery for hypotonia, poor feeding and abnormal respirations. Barium swallow evaluation prior to transfer revealed laryngeal penetration with silent aspiration and absent cough reflex. On physical examination the infant had stridor, increased oral secretions, axial hypotonia, right esotropia and facial weakness. MRI of the brain (figure 1) demonstrated a large tumour centred in the pons without reduced diffusivity on diffusion-weighed sequences and absent gadolinium enhancement consistent with a diffuse intrinsic pontine glioma (DIPG). The parents opted for palliative care without autopsy and the infant died within 7 days of birth.

Brainstem tumours constitute approximately $10-15 \%$ of all childhood brain tumours and are classified based on anatomic location within the brainstem. DIPGs represent a specific subset of brainstem tumours diagnosed during childhood by MRI alone and have the poorest survival among all paediatric brain tumours. ${ }^{1}$ Two cases of neonatal DIPGs have been reported in the literature with similar neuroimaging features. ${ }^{2}$ Our case highlights the congenital nature of a DIPG whose molecular features had been largely unknown due to its rarity and lack of biological material available for study. Most recent molecular analysis of DIPGs have demonstrated novel mutations in histone $\mathrm{H} 3$ and $\mathrm{p} 53$, as well as amplifications of platelet-derived growth factor receptor $\alpha$ in a large number of cases. ${ }^{3}$ It is the hope that these advances will lead to targeted therapies and improved survival.

\section{Learning points}

- Diffuse intrinsic pontine glioma presents in childhood with cranial neuropathy and may be diagnosed by MRI features alone without biopsy.

- Diffuse intrinsic pontine glioma may present in the neonatal period and should be considered in the differential diagnosis of neonatal brainstem tumours.

Contributors All the authors have contributed equally to the design and execution of the manuscript. All the authors agree with the contents of the submission.

\section{Competing interests None.}

Patient consent Obtained.

Provenance and peer review Not commissioned; externally peer reviewed.

\section{REFERENCES}

1 Fangusaro J. Pediatric high-grade gliomas and diffuse intrinsic pontine gliomas. J Child Neurol 2009:24:1409-17.

2 Shah NC, Ray A, Bartels U, et al. Diffuse intrinsic brainstem tumors in neonates: report of two cases. J Neurosurg Pediatr 2008;1:382-5.

3 Schroeder KM, Hoeman CM, Becher OJ. Children are not just little adults: recent advances in understanding of diffuse intrinsic pontine glioma biology. Pediatr Res 2013. Published Online First: 5 Nov 2013. doi:10.1038/pr.2013.194
To cite: Gabel BC, Yoon J, Levy ML, et al. BMJ Case Rep Published online: [please include Day Month Year] doi:10.1136/bcr-2013202270

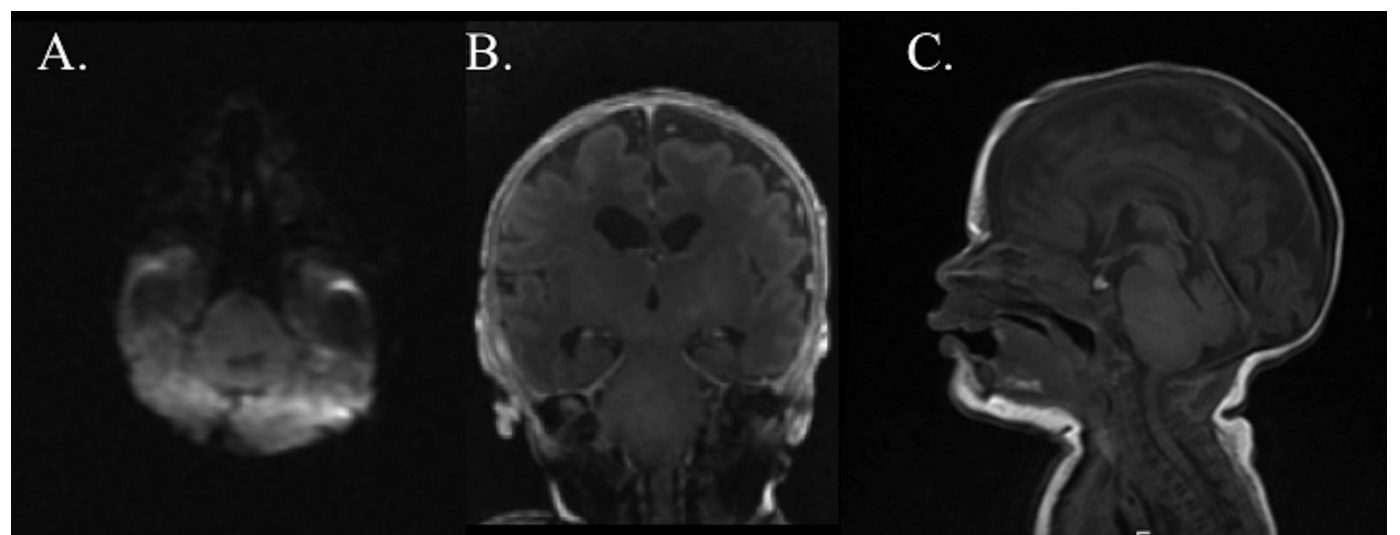

Figure 1 MRI revealing an expansile tumour in the pons without reduced diffusivity $(A)$ or gadolinium enhancement (B), and normal midline structures that fill the posterior fossa (C) consistent with a neuroradiographic diagnosis of diffuse intrinsic pontine glioma. 
Copyright 2014 BMJ Publishing Group. All rights reserved. For permission to reuse any of this content visit http://group.bmj.com/group/rights-licensing/permissions.

BMJ Case Report Fellows may re-use this article for personal use and teaching without any further permission.

Become a Fellow of BMJ Case Reports today and you can:

- Submit as many cases as you like

- Enjoy fast sympathetic peer review and rapid publication of accepted articles

- Access all the published articles

- Re-use any of the published material for personal use and teaching without further permission

For information on Institutional Fellowships contact consortiasales@bmjgroup.com

Visit casereports.bmj.com for more articles like this and to become a Fellow 